\title{
ITF

\section{Early specialization in sports: A factor to be considered in brazilian tennis players?}

\author{
Caio Cortela (BRA), Roberto Klering (BRA), Gabriel Gonçalves (BRA), Silvio Souza (BRA) \\ and Carlos Balbinotti (BRA)
}

ITF Coaching and Sport Science Review 2016; 70 (24): 19 - 21

\section{ABSTRACT}

This article discusses, under the sports early specialization's point of view, some of the probable reasons why Brazil has outstanding tennis players at junior level, but does not have the same performance in professional ranks when compared to countries with similar results in ITFJC.
Key words: Tennis; Longterm's athlete development; Early specialization Received: 18 May 2016

Accepted: 16 July 2016 Corresponding author: Caio Cortela

Email: capacitacao@fpt.com.br

\section{INTRODUCTION}

The ranking conquered by tennis players in the International Tennis Federation's Junior Circuit (ITFJC) has been considered an important tool to forecast results in the professional circuit. For years, Brazil stands out as one of the countries with the highest number of successful tennis players in this circuit, equating to some of the world's greatest powers in tennis, such as Argentina, USA and France (Reid et al., 2007). Through a brief analysis of the ITFJC boys ranking it is possible to observe that Brazil had, from 2005 to 2015, 10 tennis players among the ITFJC Top 10; two of them led this ranking and six of them were among the Top 5.

However, differently than what has been observed in other countries, Brazilian success in the ITFJC has not been converted into a high number of successful tennis players in the professional circuit. While Argentina, France and USA emerge as powers in the Men's Professional Tennis (ATP) singles rank with 8,12 and 8 tennis players, respectively, among the ATP Top 100, Brazil has only two athletes in this condition (ranking consulted on 3rd of July 2016).

Professional tennis' success is known to have a multifactorial origin. After a literature review on this topic, Crespo et al. (2003) reported that elite tennis players development is influenced by several factors, among which some are highlighted: country's tradition in the sport; competitive opportunities; training conditions; infrastructure quality; weather; coaches level and application; access to clubs and courts; and the presence of elite tennis players to serve as a role model.

With no claim to drain the topic and admitting the scenario of low productivity of studies regarding tennis in Brazil (Cortela et al., 2016), the present study aims to debate how Brazilian contextual specificities, regarding the training and competitive system, might be impacting on the development of Brazilian tennis players during athletic development stages.

TRAINING AND COMPETITIVE SYSTEM, CONSIDERATIONS REGARDING BRAZILIAN TENNIS PLAYERS

Many studies have shown problems regarding the training system (Balbinotti et al. (2004; 2005; Brandão et al., 2015; Cortela et al., 2012; Pacharoni; Massa, 2012), and in participation of Brazilian tennis players in competitions (Arena;
Böhme, 2001; Cafruni et al., 2006; Cortela et al., 2011), presenting evidences of early specialization. According to Balyi (2005), early specialization in sports takes place when the training and competitive system do not respect maturation and development stages and motor, coordinative and conditioning capacities' optimal window of trainability. Thus, excessive loads of training are applied in order to specialize a limited range of moves, which could give players expressive competitive results in a short term.

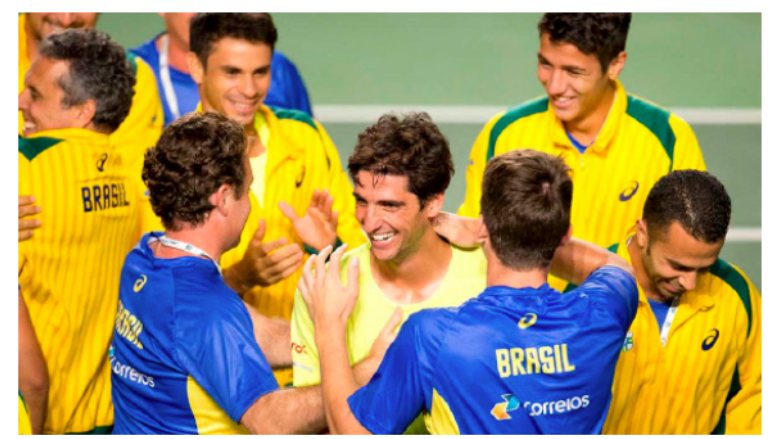

Due to its specificities, to Barbanti and Tricoli (2004), the unilateral preparation and early specialization have a greater tendency to be present in individual sports. However, tennis is characterized as a late specialization sport (Balyi, 2005; Tennis Canada, 2011), i.e. young athletes' development emphasis must be in general development of fundamental motor skills and technical/tactical skills. According to Balyi (2005), early specialization in sports with this characteristic could contribute to sports dropout, occurrence of injuries, among other factors, which limit the development of sports career.

In this scenario, Balbinotti et al. (2004; 2005) emphasize that the athletic development stage of tennis players must be marked by the construction of resources needed for future high performance, and it must occur in a diversified and balanced way. The age range from nine to 12 years-old is seen as a moment of great importance, being considered a period of optimal trainability for learning all basic and advanced techniques. These techniques should be refined during the next stage of the long-term athlete development process, contributing with the development of the all-court playing style. 
Only after the consolidation of these capabilities is that the specialization process, in order to stablish individual's style and patterns of play, must occur (Balyi, 2005; Tennis Canada, 2011). However, among Brazilian tennis players the pursuit of results in competitions seems to be influencing negatively this process. In their study with ATP Top 500 Brazilian tennis players, Cafruni et al. (2006) identified that $69 \%$ of the sample had early outstanding results (Top 10 in the national rank). According to Arena and Böhme (2001), in order to achieve good results in national competitions, the athletes need at least one or two years of specific training, given the competitive level. This means that the athletes would be initiating their specialization in this sport with an age average around seven and nine yearsold, which according to Bompa (2002) and Balyi (2005) affects the essential training load to build the resources needed for future high level performance.

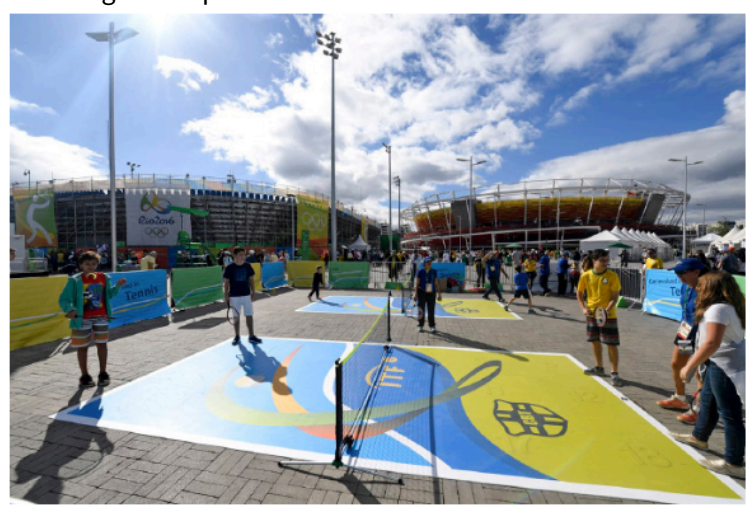

This situation is alarming, because it impacts directly the style and patterns of play adopted by the athlete. During early athlete development stages, players specialized in hitting high balls behind the baseline are capable of winning important tournaments. The lower game speed found in this period allows that a purely defensive athlete achieves good results in competitions (Fernández, 2007).

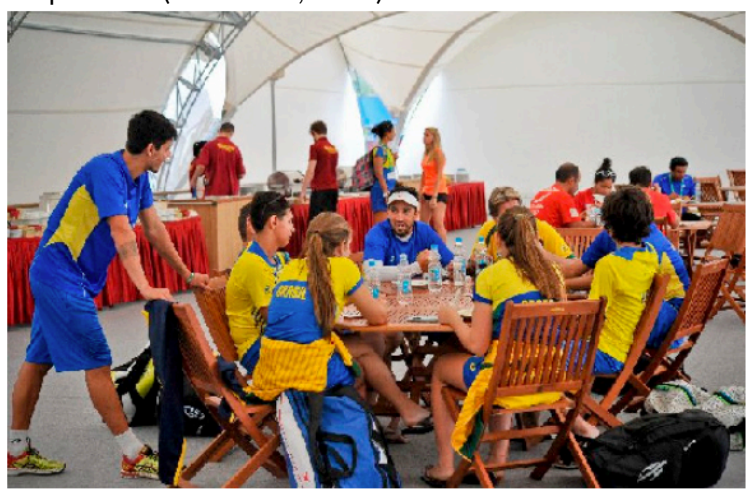

Thus, due to the technical immaturity and the incapability of generating power and/or accuracy with consistency shots, many tennis players abdicate to hit offensive shots, trying to induce their opponent to make unforced errors, without risking. These athletes end up winning many matches by having a consistent baseline game style and making few errors. It is known, however, that results in high performance tennis are determined by the efficiency in the execution of Definition Strokes (DS), characterized by power and precision in the execution. Due to their high level of difficulty, these shots should be trained since the initial stages of the athlete's development process in order to reach maturity and capacity to execute them consistently (Balbinotti et al., 2005).
In this way, it is verified that Brazilian tennis players' training sessions, during the development stage, have been drawn up in order to attend these competitive context specificities. Therefore, it is observed a higher training frequency of Preparation Strokes (PS), characterized by control and regularity, instead of training DS (Balbinotti et al., 2004; 2005, Brandão et al., 2015), which are essential for future success in tennis. According to Balbinotti et al. (2004; 2005), at a stage which training should be planned in a diversified and balanced way, a disproportional frequency of training for a specific group of shots is clearly a sign of technical/ tactical early specialization, which should be avoided.

Although it is not the main focus of this article, a similar behavior was observed among female athletes; and also an even bigger discrepancy between PS and DS training frequencies. According to Balbinotti et al. (2004), this could be one of the possible causes for the higher failure index of female Brazilian tennis players in the professional circuit when compared to male athletes, considering that the insufficient training of the DS causes incapacity of generating power and accuracy, having difficulties when competing at the speed imposed by their opponents. It is noteworthy that Brazil has not had any female athlete among WTA Top 100 for more than 20 years.

The wrong conduction and training planning alerts to other problems found in Brazilian tennis players sports development, related to the inexistency of a national model of reference and application of long

term athlete development models during the development stage. In their study with Brazilian professional tennis players, Pacharoni and Massa (2012) identified that training routines were only planned when the athletes had already shown some potential to become a pro. It was verified that important stages of the athlete's development such as learning and consolidation of the basic and advanced shots, and all-court playing style development were organized based on coaches' empiricism. This corroborates, partially, with the results presented by Balbinotti et al. (2004) who affirm that there are no differences in training volumes of Brazilian tennis players over the years, verifying that younger players (13 year-old boys) had higher training loads than older players (16 year-old boys).

\section{CONCLUSIONS}

As presented, it is observed the importance of having a reference pattern to be followed. A pattern that breaks existing paradigms in Brazilian context; that really prepares young tennis players to become competitive at a high level and not only in the ITFJC. Therefore, it is necessary that training and competitions practices seek for more offensive patterns of play as soon as the players have their basic techniques and patterns of play under control. Thus, the athletes will be familiar with the current predominant model in professional tennis sooner; having more training hours of more aggressive styles and patterns of play, understanding the importance of leading most part of the match actions and imposing their own will during a match.

\section{REFERENCES}

Arena, S. S. \& Böhme, M. T. S. (2001). Programas de iniciação e especialização esportiva na grande São Paulo. Revista Paulista de Educação Física. 14(2), 184-195.

Balbinotti, M. A. A., Balbinotti, C. A. A., Marques, A. T., Gaya, A. C. A. (2004). O treino técnico-desportivo de jovens tenistas brasileiros. Revista Brasileira de Ciência do Esporte. 18(3), 51- 72.

Balbinotti, M. A. A., Balbinotti, C. A. A., Marques, A. T., Gaya, A. C. A. (2005). Estudo descritivo do inventário do 
treino técnico- desportivo do tenista: resultados parciais segundo o 'ranking'. Revista Portuguesa de Ciências do Desporto. 5(1), 4958.https://doi.org/10.5628/rpcd.05.01.49

Balyi, I. (2005). Long-term Athlete Development. Canadian Sport for Life. Disponível em: <http://www.Itad.ca/Content/

Resources\%20and\%20Downloads/Downloads.asp>. Acesso em: 04/12/2007.

Barbanti, V. \& Tricoli, V. (2004). A formação desportiva. In: A Gaya, A Marques \& G Tani (organizadores). Desporto para crianças e jovens: Razões e finalidades. Porto Alegre, UFRGS editora, 199- 215.

Bompa, T. O. (2002). Treinamento total: para jovens campeões. Barueri, Manole.

Brandão, M. N., Cortela, C. C., Aburachid, L. M., Balbinotti, C. A. A. \& Coelho e Silva, M. J (2015). A trajetória de tenistas infantojuvenis: idade de iniciação, treinamento técnico, cargas, lesões e suporte parental. Rev. Educ. Fís/UEM. 26(1),3142.https://doi.org/10.4025/reveducfis.v26i1.2454 7

Cafruni, C. \& Marques, A., Gaya, A. (2006). Análise da carreira desportiva de atletas das regiões sul e sudeste do Brasil. Estudo dos resultados desportivos nas etapas de formação. Revista Portuguesa de Ciências do Desporto. 6(1), 64.https://doi.org/10.5628/rpcd.06.01.55

Cortela, C. C., Nascimento, R. J.; Kist, C. \& Rocha, D. N. (2011). A carga de treinamento e competição dos tenistas infantis paranaenses: um estudo comparativo sobre tenistas com diferentes níveis de desempenhos máximos. Revista Eletrônica FAFIT/FACIC. 2(1), 113.https://doi.org/10.5216/rpp.v13i3.9653

Cortela, C. C., Silva, M. J. C., Fuentes, J .P . G. \& Rocha, D. N. (2012) Resultados esportivos no escalão júnior e desempenhos obtidos na etapa de rendimentos máximos: Uma análise sobre a carreira dos tenistas Top 100. Revista Mackenzie de Educação Física e Esporte, 11(1), 125-133.

Cortela, C. C., Gonçalves, G. H. T., Klering, R. T., Balbinotti, C. A. A. (2016). O "estado da arte" das publicações sobre tênis em periódicos nacionais. Coleção Pesquisa em Educação Física, 15(2), 143-151.

Crespo, M., Reid, M., Miley, D. \& Atienza, F. (2003). The relationship between professional tounament structure on the national level and success in menřs professional tennis. Journal of Science and Medicine in Sport. 6(1), 3-13.https://doi.org/10.1016/S14402440(03)80003-8

Fernandéz, A. L. (2007). Estudio de la progresión de los semifinalistas de los campeonatos de españa de categoría infantil disputados entre los años 1988 y 1992. Disponível em: <http://www. itftennis.com/shared/medialibrary/pdf/original/IO_ 29399_original.PDF>. Acesso em: 04/02/2008.

Pacharoni, R. \& Massa, M. (2012). Processo de formação de tenistas talentosos. Motriz. 18(2), p.253261.https://doi.org/10.1590/S198065742012000200005

Tennis Canada (2011). Long term athlete development plan for the sport of tennis in Canada. Disponível em: $<$ http://www. tenniscanada.com/misc/LTADallenglish.pdf>. Acesso em: 28 abr. 2011

Reid M, Crespo M, Santilli L, Miley D \& Dimmock J (2007). The importance of the International Tennis Federation's junior boys'circuit in the development of professional tennis players. Journal of Sports $\begin{array}{ll}\text { Sciences, } & \text { 25(6), }\end{array}$ 672.https://doi.org/10.1080/0264041060081193 2

RECOMMENDED ITF TENNIS ACADEMY CONTENT (CLICK BELOW)

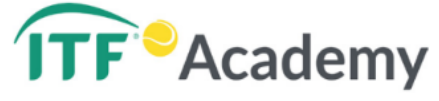

Copyright (c) Caio Cortela, Roberto Klering, Gabriel Gonçalves, Silvio Souza and Carlos Balbinotti 2016

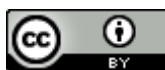

This text is under a Creative Commons BY 4.0 license

You are free to Share - copy and redistribute the material in any medium or format - and Adapt the content - remix, transform, and build upon the material for any purpose, even commercially under the following terms:

Attribution: You must give appropriate credit, provide a link to the license, and indicate if changes were made. You may do so in any reasonable manner, but not in any way that suggests the licensor endorses you or your use.

CC BY 4.0 license terms summary $\quad$ CC BY 4.0 license terms 